\title{
Habitat Heterogeneity and Spatio-Temporal Distribution of Macrobenthos in in a Tropical Estuarine Mangrove Ecosystem
}

\author{
S. M. Parvez Al Usmani*
}

D. M's College and Research Centre, Assagao, Mapusa - 403507, Goa, India; parvez_goa@yahoo.com

\begin{abstract}
This paper deals with spatio-temporal distribution of macrobenthos and their relationship with physico-chemical environment and sediment properties in estuarine mangrove ecosystem of Chorao, Goa. The complex mangrove habitats provide nutrient and play vital role in the establishment of healthy mangrove fauna. The mangrove of Chorao is inhabited by 14 species of mangrove and associated flora in different substrata. The macrofaunal density in the four study stations varied significantly. Total numerical count was 7960 at C1, 3300 at C2, 6705 at C3 and 7075 at C4. The wet weight biomass was 27.18 at $\mathrm{C} 1,17.62$ at $\mathrm{C} 2,15.85$ at $\mathrm{C} 3$ and 24.30 at $\mathrm{C} 4$. There was strong seasonality in the occurrence of fauna in the study area. The average macrofaunaltaxa was dominated by polychaeta (55\%), crustacea (26\%) and mollusca (14\%). The other groups like nematode, echiurida and nemertenea was insignificant. The epibenthic feeding forms of polychaetes and scavengers/browsers of crustacean were more common in the sandy substratum, while deposit feeders were common in muddy substratum at Chorao mangrove. The result of the present study suggests that mangrove ecosystem with different substrata and physico-chemical parameters supports varied fauna and had different effect on the benthic community.
\end{abstract}

Keywords: Abundance, Distribution, Environmental Parameters, Macrobenthos, Mangroves

\section{Introduction}

The mangrove ecosystem is ideally situated at the inter phase between terrestrial and marine environment. They are predominant habitats in the tropics and subtropics and have been reported to be of immense ecological and socioeconomic significance and hence categorized under ecologically sensitive zone ${ }^{\underline{13}}$. As a detritus-based ecosystem, leaf litter from the mangroves provides the basis for adjacent aquatic and terrestrial food webs ${ }^{1}$. It also serves as breeding, feeding and nursery grounds for most of the commercially important finfish and shellfishes, on which thousands of coastal people depend for their livelihood (Manson, et al. 2005). India has approximately $2.7 \%$ of the world's mangroves, covering an estimated area of 4,827 sq $\mathrm{km}$. Almost $80 \%$ of the mangrove forests are located along the east coast and the remaining $20 \%$ are located on the west coast $\underline{13}$.

Benthic macro fauna are important components of coastal food webs. Many fish species in estuarine ecosystems are strongly dependent taxa available that reside on the sediment surface, such as amphipods, mysids and surface deposit feeders $\frac{23,21}{2}$. Studies on benthic diversity, population dynamics and species diversity of mangrove ecosystem and their relationship to the environmental conditions are important for understanding the mangrove ecosystem and their sustainable use ${ }^{25}$. The climate change and the anthropogenic processes are bringing sequential changes in the coastal marine environment. The understanding of such changes is essential for resource management $\underline{22}$. Water quality and benthos characteristics have been investigated in coastal ecosystems around the

*Author for correspondence 
world ${ }^{26}$. The health of benthic communities is related to water quality conditions in fringing communities, such as mangroves. Therefore a study on structure, composition and seasonal distribution of macrobenthic fauna in the intertidal areas of the a tropical mangrove ecosystem at Chorao Island Goa was carried out with reference to environmental characteristics. The result is reported in this communication.

\section{Materials and Method}

\subsection{Study Area}

The Mandovi estuary lies within latitude $15^{\circ} 09^{\prime}$ and $15^{\circ} 33^{\prime}$ North and longitude $73^{\circ} 45^{\prime}$ and $74^{\circ} 14^{\prime}$ east in Goa. It is seasonally influenced by semi diurnal tides that flow westwards and empty into the Arabian Sea at Aguada Bay on central west coast of India, carrying the waste from the adjacent agriculture lands and mining industries, in addition to domestic municipal effluents. The present study

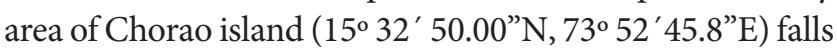
within Mandovi estuary. The Chorao is the largest among the islands of Goa and had great history behind. The west-

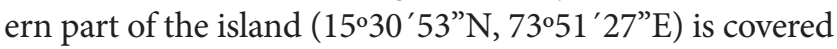
with thick mangrove forest and is declared a bird sanctuary called Salim Ali Bird sanctuary. The total area of the sanctuary is 178 hectares. There are 14 species of mangrove with low vegetation having zonation of Rhizophoramucronata, Avicenniaofficinalis, Bruguiraapiculata Sonnertia alba clearly identifiable within the sanctuary. It provides refuge to wide variety of avifauna ${ }^{6}$. The details of stations are presented in Figure 1. The present study was undertaken in four stations, occupied by dominant mangrove forest. The four sites in the fringe of mangrove varied in microclimatic nitche. The distributions of stations include one each in the following area:

- Avicennia officinalis zone - Includes small patch of $A$. marina, $A$. alba growing in the edge of the eastern side (station $\mathrm{C} 1$ ) dominated by the silty sand.

- Rhizophora mucronata zone - Includes patches of $R$. apiculata on the western side (station C2) dominated by muddy sediment..

- Bruguiera apiculata zone - Forms dense stand with B. cylindrica in the central part (station C3) in a sandy muddy sediment.
- Sonnertia alba zone - Grows with S. caseolaris spreads in the north western side of the sanctuary (station C4) in a sandy silt sediment.

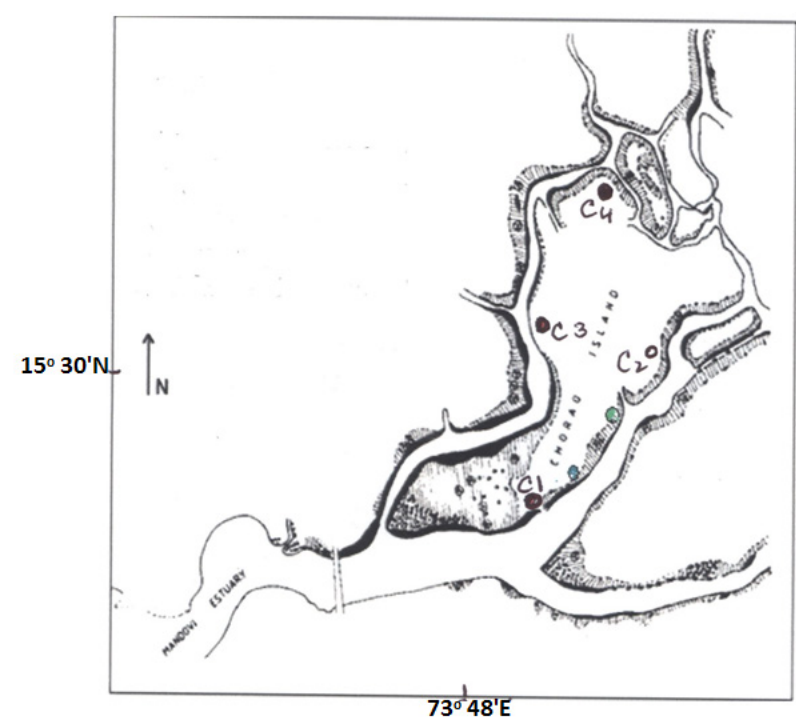

Figure 1. Map of Chorao island showing location of study area.

\section{Sample Collection and Analysis}

Sediment in replicate were collected monthly (March 2014-February 2015) using a metal quadrant of $25 \mathrm{~cm} \times$ $25 \mathrm{~cm}$ size up to a depth of $15 \mathrm{~cm}$. The macrofauna was recovered after sieving through a $0.5 \mathrm{~mm}$ mesh sieve in the field and the sample was preserved in 5\% buffered formalin and brought to the laboratory. Animals were sorted and identified to taxa level. Interstitial water from each station was collected for the dissolved oxygen, salinity temperature and $\mathrm{pH}$. The environmental parameters were analyzed by following the method given in ${ }^{3}$. Sediment texture was determined by the method of ${ }^{9}$. The organic carbon of the sediment was analyzed by wet oxidation method $\stackrel{8}{*}$. Fauna were identified to the lowest 1 taxonomic level with the help of literature; The density of benthos was expressed as No. $/ \mathrm{m}^{2}$.

\section{Results}

\subsection{Physico-Chemical Characteristics}

Table 1 shows the environmental parameters in the study area; Total rainfall during June 2014-October 2014 was $2810.9 \mathrm{~mm}$ and relatively high rain fall was observed in 
Table 1. Seasonal variation in average value of environmental parameters at the study stations

\begin{tabular}{|l|l|l|l|l|l|}
\hline Season & Parameters & C1 & C2 & C3 & C4 \\
\hline \multirow{4}{*}{ Pre monsoon } & Temperature $\left({ }^{\circ} \mathrm{C}\right)$ & 29.8 & 30.2 & 29.5 & $29 . .7$ \\
\cline { 2 - 6 } & Salinity $(\mathrm{psu})$ & 31.55 & 30.24 & 29.65 & 30.42 \\
\cline { 2 - 6 } & $\mathrm{DO}(\mathrm{ml} /) 1$ & 3.98 & 3.46 & 3.02 & 3.29 \\
\cline { 2 - 6 } & $\mathrm{pH}$ & 7.6 & 6.8 & 7.7 & 7.4 \\
\hline \multirow{3}{*}{ Monsoon } & Temperature $\left({ }^{\circ} \mathrm{C}\right)$ & 22.8 & 25.0 & 26.0 & 24.2 \\
\cline { 2 - 6 } & Salinity $(\mathrm{psu})$ & 21.14 & 23.57 & 20.28 & 19.66 \\
\cline { 2 - 6 } & $\mathrm{DO}(\mathrm{ml} / \mathrm{l})$ & 5.18 & 4.36 & 5.05 & 4.89 \\
\cline { 2 - 6 } & $\mathrm{pH}$ & 7.2 & 8.0 & 7.4 & 7.4 \\
\hline \multirow{3}{*}{ Post monsoon } & Temperature $\left({ }^{\circ} \mathrm{C}\right)$ & 28.4 & 29.0 & 28.6 & 28.2 \\
\cline { 2 - 6 } & Salinity $(\mathrm{psu})$ & 28.74 & 27.15 & 29.14 & 26.56 \\
\cline { 2 - 6 } & $\mathrm{DO}(\mathrm{ml} / \mathrm{l})$ & 4.45 & 4.14 & 5.22 & 4.16 \\
\cline { 2 - 5 } & $\mathrm{pH}$ & 8.2 & 7.9 & 7.6 & 7.4 \\
\hline
\end{tabular}

July-August 2014 which is expected. The temperature of interstitial water ranged from $29.5^{\circ} \mathrm{C}-30.2^{\circ} \mathrm{C}$ in premonsoon 22.8 to $26.0^{\circ} \mathrm{C}$ in monsoon and 28.2 to 29.0 ${ }^{\circ} \mathrm{C}$ in post-monsoon season. The highest temperature was in April-May and lowest in the monsoon season. Salinity ranged from 29.65-31.55 psu in pre-monsoon 19.66 to 23.57 in monsoon and 27.15 to 29.14 psu in postmonsoon season. Low salinity in monsoon is the result of precipitation and freshwater runoff; Dissolved oxygen was in the range of 3.02 to $3.98 \mathrm{ml}$ in pre-monsoon, 4.36 to $5.18 \mathrm{ml}$ in monsoon and 4.14 to $5.22 \mathrm{ml}$ in post-monsoon season. Stations 1 and 2 exhibited the highest DO values throughout the study period. Low DO concentrations recorded during the summer season which in part is attributable to higher water temperature. $\mathrm{pH}$ ranged from were 6.8-7.7 in pre-monsoon, 7.2 to 8.0 in monsoon and 7.4 to 8.2 in post-monsoon season. The lowest $\mathrm{pH}$ was at Station C2 during the monsoon season and the highest was 8.2 at Station 1 during the post monsoon season.

\subsection{Mangrove Sediment Characteristics}

The percentage sediment percentage is given in Table 2. Mangrove substratum was mainly composed of sand with an admixture of silt and clay in different proportion (percentage). The average sand fraction ranged between 12.5-60.4\% in pre-monsoon, $18.8-69.2 \%$ in monsoon and $16.2-70.5 \%$ in post monsoon. The fraction of silt was in the range of $28.5-45.5 \%$ in pre-monsoon, $21.4-40.3 \%$ in monsoon and $25.3-47.3 \%$ in post monsoon respec- tively. Similarly, the fine particles of clay mud was in the range of $11.1-58.9 \%$ in pre-monsoon $8.3-46.7 \%$ in monsoon and $4.2-55.3 \%$ in the post-monsoon. The sediment organic carbon was in the range of 19.4 to $34.6 \%$ at $\mathrm{C} 1$, 19.8 to $38.6 \%$ at C2, 19.8 to $37.4 \%$ at C3 and 21.9 to 38.2 $\%$ at $\mathrm{C} 4$ respectively. Changes in sediment composition were mainly due to transport of sediments by tides and currents. The sediment type was silty sand, muddy, silty clay and sandy silt. The average organic carbon in sediment was similar at all stations with seasonal variations. The values were in the range of 19.4 to 34.6 at $\mathrm{C} 1,19.8$ to 38.4 at C2, 19.8 to 37.4 at C3 and 21.9 to $38.2 \mathrm{mg} / \mathrm{g}$ at C4, respectively (Table 3 ).

\subsection{Macrofaunal Abundance}

The density and abundance of macrofauna is presented in Table 4 . The average density $\left(\right.$ no. $\left./ \mathrm{m}^{2}\right)$ ranged from 280 1350 at C1, 125-450 at C2, 180-875 at C3 and 225-1025 at $\mathrm{C} 4$ respectively. There was a strong seasonal variation in the abundance of macrobenthic fauna. The lowest benthic fauna was observed in the wet monsoon season while the highest was observed in the pre-monsoon season. The summer season is the time of breeding of most of the intertidal fauna in the mangrove environment that is why the highest density was recorded in this period. It is also responsible in the significant variation of density of macrofauna. Station-wise, the maximum density was recorded in the silty sand at $\mathrm{C} 1$ and minimum at $\mathrm{C} 2$ in muddy sediment. Total wet weight biomass also varied significantly. 
The larger heavier organisms were responsible for significant variation in the standing crop of benthos.

Table 2. Average value (\%) of sediment characteristic of the mangrove of Chorao

\begin{tabular}{|l|l|l|l|l|l|}
\hline Season & $\begin{array}{l}\text { Sediment } \\
\text { type }\end{array}$ & C1 & C2 & C3 & C4 \\
\hline \multirow{3}{*}{$\begin{array}{l}\text { Pre- } \\
\text { monsoon }\end{array}$} & Sand & 60.4 & 26.2 & 12.5 & 48.3 \\
\cline { 2 - 6 } & Silt & 28.5 & 45.5 & 29.6 & 35.2 \\
\cline { 2 - 6 } & Clay & 11.1 & 39.3 & 58.9 & 16.2 \\
\hline \multirow{4}{*}{ Monsoon } & Sand & 69.2 & 38.2 & 18.8 & 59.7 \\
\cline { 2 - 6 } & Silt & 22.5 & 40.3 & 24.5 & 21.4 \\
\cline { 2 - 6 } & Clay & 8.3 & 21.5 & 56.7 & 18.9 \\
\hline \multirow{2}{*}{$\begin{array}{l}\text { Post- } \\
\text { monsoon }\end{array}$} & Sand & 70.5 & 32.7 & 16.2 & 42.5 \\
\cline { 2 - 6 } & Silt & 25.3 & 47.5 & 28.5 & 40.3 \\
\cline { 2 - 6 } & Clay & 4.2 & 20.0 & 55.3 & 18.2 \\
\hline
\end{tabular}

Table 3. Total sediment organic carbon $(\mathrm{mg} / \mathrm{g})$ at the study station

\begin{tabular}{|l|l|l|l|l|}
\hline Month & C1 & C2 & C3 & C4 \\
\hline March '14 & 28.5 & 27.6 & 22.5 & 29.2 \\
\hline April & 24.7 & 28.5 & 19.8 & 27.6 \\
\hline May & 21.8 & 26.7 & 21.7 & 22.8 \\
\hline June & 30.3 & 29.8 & 28.5 & 28.6 \\
\hline July & 34.6 & 38.4 & 34.2 & 35.2 \\
\hline August & 31.5 & 36.7 & 37.4 & 38.2 \\
\hline September & 22.9 & 24.5 & 30.1 & 34.2 \\
\hline October & 24.5 & 19.8 & 24.2 & 21.9 \\
\hline November & 23.6 & 23.4 & 21.6 & 23.2 \\
\hline December '14 & 19.4 & 23.8 & 19.8 & 26.2 \\
\hline January'15 & 21.5 & 22.6 & 29.2 & 25.9 \\
\hline February '15 & 23.5 & 27.2 & 26.3 & 27.5 \\
\hline
\end{tabular}

\subsection{Faunal Composition}

Figure 2 illustrates that there was a preponderance of marine forms in the macroinvertebrate assemblage of the present study. The dominant groups representing the fauna were polychaeta crustacean and mollusca (Figure 2 ). The polychaetes contribution was in the range of 42 to $56 \%$ and crustaceans contributed from 28 to $42 \%$. The mollusca contribution was 11 to $15 \%$. The other group contributed from 5 to $11 \%$. The polichaetes had the more representation of deposit feeding and predatory forms while the crustacean had the dominance of amphipoda and isopoda. Decapos were common at most stations and the post larvae of shrimp and crabs were found at all the stations. The mollusca was mainly represented by gastropoda and bivalvia. The other group is represented by Echiurid worms, nemertean worms, nematode and oligochaeta.

Table 4. Seasonal abundance in macrofaunal density $\left(\right.$ no. $\left./ \mathrm{m}^{2}\right)$ at the study sites of the Chorao mangrove

\begin{tabular}{|l|l|l|l|l|}
\hline Month & C1 & C2 & C3 & C4 \\
\hline March '14 & 775 & 225 & 675 & 480 \\
\hline April & 825 & 350 & 525 & 775 \\
\hline May & 1350 & 375 & 850 & 1025 \\
\hline June & 400 & 175 & 500 & 475 \\
\hline July & 325 & 125 & 250 & 275 \\
\hline August & 280 & 100 & 180 & 325 \\
\hline September & 325 & 175 & 325 & 275 \\
\hline October & 400 & 250 & 375 & 425 \\
\hline November & 380 & 425 & 525 & 475 \\
\hline December '14 & 550 & 400 & 675 & 550 \\
\hline January '15 & 625 & 450 & 825 & 850 \\
\hline February'15 & 925 & 375 & 750 & 975 \\
\hline Biomass (g/m $\left.{ }^{2}\right)$ & 2718 & 1762 & 1585 & 2430 \\
\hline
\end{tabular}
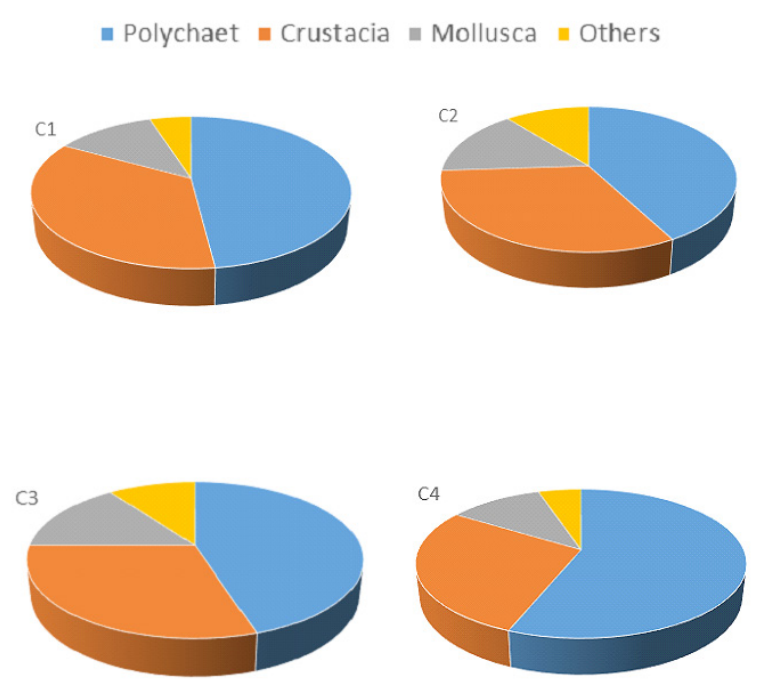

Fig. 2: Percentage composition of major taxa at the study stations.

Figure 2. Percentage composition of major taxa at the study stations. 


\section{Discussion}

\subsection{Water Quality Parameters}

Mangrove sediments are highly anaerobic rich in sulphide and organic matter ${ }^{16}$. Variations observed in water quality parameters at the study stations can be attributed to hydrographical patterns in climate and biological activity $\stackrel{11}{ }$. Generally, water temperature is influenced by the intensity of solar radiation, evaporation, freshwater influx and cooling and mixing up with ebb and flow from adjoining waters of Mandovi estuary ${ }^{12}$. In the present study, summer peaks and monsoonal troughs in water temperatures were similar to those reported by others $\underline{11}$. Salinity acts as a limiting factor in the distribution of living organisms and its variation caused by dilution and evaporation influences faunal distribution in the intertidal zone $\frac{17}{7}$. In the present study, salinity at all the four stations was high in summer and low in the monsoon season indicating that variation in salinity at study sites was affected by freshwater runoff entering the creek systems of estuarine mangrove at Chorao. The high organic carbon associated with finer sediment is a common feature observed by others also $\frac{12,18}{}$.

Higher $\mathrm{pH}$ observed in summer season could be attributed to the removal of $\mathrm{CO}_{2}$ by the photosynthetic organisms and the lower $\mathrm{pH}$ during monsoon season could be due to the dilution of saline water by freshwater inflow ${ }^{1}$. The relatively low DO values observed in the summer are attributable to the prevalence of high saline waters in the mangrove channels from Mandovi estuary as well as fluctuations in temperature and salinity. By contrast sediments with a mixture of organic matter, sand and clay, but low sulphide, seem to support higher abundances of benthic marcofauna. Distribution and ecology of benthic communities in relation to station and season of the present study showed influence of the environmental parameters. This is in support of earlier studies ${ }^{1,17}$.

The mangrove fauna basically derive from adjacent estuarine and marine environment and its stratification depends mainly on tidal inundation by saline water ${ }^{7}$. Limited quantitative information has been published on estuarine mangrove habitats of Goa including macroinvertebrate fauna and their relationship to environmental factors. This study provides a baseline for the distribution, abundance and diversity of benthic macroinvertebrate fauna of Chorao mangroves in Goa. The occurrence of different taxa in the present study is similar to that observed by others on the east and west coast of India 27,4 . However the macrobenthicdensity observed in this study (140-1113 no. $/ \mathrm{m}^{2}$ ) were higher than that reported by ${ }^{2}$ in Mandovi-Zuari estuarine system. The densities were comparable to those observed in the other mangrove swamps of India ${ }^{26}$. The high densities recorded in the pre- and post-monsoon season could be due to high temperatures and turbidity coupled with stable environmental conditions ${ }^{24}$. Post-monsoon season (Nov-Feb) peaks in density and higher abundance in pre-monsoon were also reported for the west coast of India ${ }^{5}$. These studies have reported the dominance of polychaetesover mollusks in mangrove fauna due to silty clay and muddy substratum. Soft mangrove substrates favor tube dwellers over diggers and burrowing animals, such as bivalves. The present study corroborates it. The high diversity of polychaete indicates favorable ecological conditions that exist in mangrove ecosystems (Ajmal and Murugesan; 2005).

\section{Conclusions}

This study provides insights into the effects of a range of environmental parameters on macro benthic communities of Chorao mangroves in Goa. Altogether 76 species of benthic macroinvertebrate fauna, belonging to five major groups, were identified at the four sampling stations. Station 1 was dominated by sandy sediment, high salinity, high DO and relatively low sulphide levels. The region displayed the high abundance and standing crop biomass. The temporal distribution of benthic macro invertebrate fauna exhibited the highest density during pre-monsoon season. The decrease of benthos during the monsoon may be attributable to low temperatures and salinities. Considering the importance of flora and fauna of mangrove and constant threat regular monitoring of this ecosystem is required to assess its health.

\section{Acknowledgement}

The author is thankful to the Principal Dr. D. B. Arolkar for encouragement.

\section{References}

1. Alongi DM, Christoffersen P. Benthic infauna and organism-sediment relations in a shallow, tropical coastal area: Influence of out welled mangrove detritus and physical disturbance. Mar Eco Prog Ser. 1992; 81:229-45. https://doi.org/10.3354/meps081229 
2. Ansari, ZA, Ingole BS, Banerjee G, Parulekar AH. Spatial and temporal changes in benthic macrofauna from Mandovi and Zuari estuaries, west coast of India. Indian J Mar Sci. 1986; 15:223-9.

3. APHA. Standard methods for the examination of water and wastewater 20th Ed. Washington, DC: APHA; 1998.

4. Bandekar PD, Naik UG, Hara SB. Diversity status of benthic macro polychaetes species in estuarine region of Karwar, West Coast of India. International Journal of Fisheries and Aquatic Studies. 2017; 5(1):216-9.

5. Bhat UG, Studies on Benthos of Kali estuary, Karwar. [Ph.D. Thesis]. Marine Biol, Karnatak University. 1984.

6. Borges SD, Shanbhag AB. Additions to the avifauna of Goa, India. Journal of the Bombay Natural History Society. 2007; 104(1):98-101.

7. Chong VC, Sasekumar A, Leh MUC, Cruz RD. The fish and prawn communities of a Malaysian coastal mangrove system with comparisons to adjacent mud flats and inshore waters. Estuarine, Coastal and Shelf Science. 1990; 31:703-22. https://doi.org/10.1016/0272-7714(90)90021-I

8. El Wakeel SK, Riley JP. The determination of organic carbon in marine muds. J Cons Perm Int Explo Mer. 1956;22:180-3. https://doi.org/10.1093/icesjms/22.2.180

9. Folk RL. Petrology of sedimentary rock. Hemphills Ausdty in Texas. 1968. 170.

10. Jagtap TG, Chavan V, Untawale AG. Mangrove ecosystems of lndia: A need for protection. Ambio. 1993; 22(4):252-4.

11. Jagtap TG. Ecological studies in relation to the mangrove environment along the Goa Coast, India. [Ph. D. Thesis]. Shivaji University, Kolhapur. 1985.

12. Jagtap TG. Seasonal distribution of organic matter in mangrove environment of Goa. Indian Journal of Marine Sciences. 1987; 16:103-6.

13. Kathiresan K. A review of studies on Pichavaram mangrove, southeast India. Hydrobiol. 2000; 430:185-205. https://doi.org/10.1023/A:1004085417093

14. Kathiresan K, Bingham BL. Biology of mangroves and mangrove ecosystems. Advances in Marine Biology. 2001; 40:81-251. https://doi.org/10.1016/S0065-2881(01)40003-4

15. Khan AS, Murugesan P. Polychaete diversity in Indian estuaries. Indian J Mar Sci. 2005; 34(1):114-9.

16. Kumar RS. Distribution of organic carbon in the sediments of Cochin mangroves, south west coast of India. Indian J Mar Sci. 1996; 25:56-61.
17. Kumar RS. A review of biodiversity studies of soil dwelling organisms in Indian mangroves. Zoos Print. 2000; 15(13):221-7. https://doi.org/10.11609/JoTT.ZPJ.15.3.221-7

18. KUMAR RS. Macrobenthos in the mangrove ecosystem of Cochin backwaters, Kerala (Southwest coast of India). Indian J Mar Sci. 1996; 24:56-61.

19. Kumar RS. Intertidal zonation and seasonality of benthos in a tropical mangrove. Int J Ecol Environ Sci.2001; 2:199208.

20. Kumar RS. Vertical distribution and abundance of sediment dwelling macro invertebrates in an estuarine mangrove biotope, southwest coast of India. Indian J Mar Sci.1997; 26:26-30.

21. Kumar PS, Khan AB. The distribution and diversity of benthic macroinvertebrate fauna in Pondicherry mangroves, India. Aquatic Biosystem.2013;9:1-15.https://doi.org/10.1186/20469063-9-15 PMid:23937801 PMCid:PMC3751066

22. Onuf CP, Teal JM, Valiela L. Interactions of nutrients, plant growth and herbivory in a mangrove ecosystem. Ecology. 1997; 58:514-26. https://doi.org/10.2307/1939001

23. Parulekar A. Benthic fauna of mangrove environment. Conservation of Mangrove Forest Genetic Resources: A training manual. Sanjay VD, Balaji V, eds. CRSARD; Chennai, 128. 1994.

24. Patra KC, Bhunia AB, Mitra A. Ecology of macrobenthos in a tidal creek and adjoining mangroves in West Bengal, India. Environ Ecol. 1990; 118:539-47.

25. Saravanan KR, Ilangovan K, Khan AB. Floristic and macro faunal diversity of Pondicherry mangroves, South India. TroEco. 2008; 49(1):91-4.

26. Samidurai K, Saravanakumar A, Kathiresan K. Spatial and temporal distribution of macrobenthos in different mangrove ecosystems of Tamil Nadu Coast, India. EnviroMoni Asses. 2012; 184(7):4079-96. https://doi.org/10.1007/ s10661-011-2245-x PMid:21833734

27. Thilagavathi B, Varadharajan D, Babu A, Manoharan J, Vijayalakshmi S, Balasubramanian T. Distribution and diversity of macrobenthos in different mangrove ecosystems of Tamil Nadu Coast, India. J Aquaculture Research Development. 2013; 4:6-12. 